\title{
Improving the Soft Power of Chinese Culture and Enhancing the Countermeasures of Cultural Confidence
}

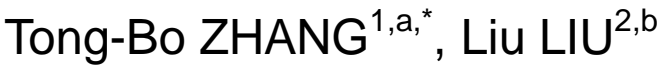 \\ ${ }^{1}$ School of Marxism, Tianjin University of Technology, Tianjin, China \\ ${ }^{2}$ School of Marxism, Tianjin University of Technology, Tianjin, China \\ a459924348@qq.com, b1031975536@qq.com \\ ${ }^{*}$ Corresponding author
}

Keywords: Culture, Cultural soft power, Countermeasures

\begin{abstract}
The promotion of soft power of Chinese culture is crucial for the comprehensive development of a country. With the deepening degree of the globalization, our country has made certain achievement in the promotion of cultural soft power since the reform and opening up. However, there are still many shortcomings in the process of promotion. Only if we have a deep reflection on the current situation of our country's cultural soft power and strengthen our understanding of the necessity of promoting of cultural soft power can we better promote the current development of China's socialist culture.
\end{abstract}

\section{Introduction}

Over the past 30 years, China has always adhered to the practical principle, strictly abided by its own pace of development and effectively integrated into the international community. In the context of globalization, the mainstream culture of our country has been affected to some degree, but the development of our country's cultural soft power has made important achievements. This has laid a certain foundation for the next promotion of cultural soft power.

\section{The Current Situation of China's Cultural Soft Power}

\section{Opening up a New Mode of Socialist Development with Chinese Characteristics}

Judging from the current situation, many regions and countries in the world have completely applied and unscientifically replicated the western liberal economic model. Its consequence is that the country's economic development is in trouble because of the lack of integration with the country's real problems and the wrong use of the idea of "bring doctrine". Many countries are still struggling with the effects of the financial crisis, especially in some developing countries. Coping western economic development mode, not only have these countries not solved the development problem of home country, but also have made the society and people immersed in a more chaotic social situation.

On the contrary, development of China has developed a brand-new development model with Chinese characteristics, combined with China's actual national conditions and the foundation for social development, and has opened up a unique road for China's development.

The route that China takes to participates in the globalization process is not an isolated route of one-way development, but a combination of the actual needs of China's rise. China have scientifically drawn lessons from the new development mode of international society, uses the brand-new guiding idea and patterns with Chinese characteristics to participates in 
the internationalization development. This kind of development model is having a broad and profound impact throughout the world, providing important inspirations for countries that cannot stand on their own but also want to participate in the international community. To a certain extent, this shows the solid foundation of the promotion of China's cultural soft power in concept and mode.

\section{The Theory of Peaceful Diplomacy has been Recognized by the World.}

Over the years, China has consistently followed the path of "peaceful diplomacy", and has always advocated a world of peace and harmony. At the same time, under the guidance of this concept our country has successfully demonstrated to international community the charm of our country's peaceful diplomacy and culture. In fact, China's concept of a harmonious world has not only made China's cultural soft power enhanced, but also has brought China closer to the rest of the world. Our country has promoted the prosperity and development of international economy and society and has highlighted. In the context of globalization, China has promoted the prosperity and development of the international economy and society, and highlighted the superiority of China as a big oriental country in the ideological field. This has further earned my country the respect of the international community.

\section{Actively Carry out Activities to Publish Chinese Culture abroad}

At present, our country is improving its comprehensive national strength in an all-round way. In the context of globalization, China's international status has been greatly enhanced, and its comprehensive national strength has been constantly strengthened. For example, the Chinese language and culture is getting more and more welcome and learned by the people of other countries.

China's Ministry of Education began in 2002, planning to build overseas Chinese language extension agencies, which was officially named Confucius Institutes in March 2004. In just a few years of the construction, Confucius Institutes has made an irreplaceable and important contribution to promoting the worldwide Chinese fever. As a result of cultural exchange activities organized by various countries in the world, such as the year of tourism and cultural exchange between China and Russia, China has further transmitted its excellent national culture to the international community.

The outstanding culture of China is transmitted to the international community by different carriers, meanwhile, and the applications for intangible cultural heritage have been conducted in various regions of China. The people's awareness of protecting and developing our national culture has been constantly rising. Our country has made the world know about China by means of the opportunity of cultural transmission, and strengthened the influence, attraction and affinity of Chinese culture.

\section{The Problem in Our Country's Cultural Soft Power}

From the current situation, compared with western developed countries, China's cultural soft power is still far away. Although China has certain advantages in strengthening the promotion of cultural soft power, it also faces severe challenges.

\section{Lack of Scientific and Rational Policy System of Cultural Soft Power}

Under the background of globalization, the market economy of our country has enjoyed unprecedented prosperity and development. In the market economy system, people's demand 
for material has further increased. Meanwhile, the original social, political, economic and cultural patterns have been broken, people's traditional ideas and concepts are undergoing profound changes under the impact of multi-culture.

Nevertheless, at present, China's cultural soft power is being built, but the cultural management mode is still more traditional. Therefore, China is facing the dilemma of cultural choice. On the one hand, in the fierce collision of multi-culture, to improve the soft power of culture, we must have a set of sound and scientific rigid system as the necessary support. In the process of developing socialist culture, only in this way can we rationally choose and draw lessons from foreign cultures, promote the reform of China's cultural industry and promote people's consciousness of culture.

On the other hand, most of the existing cultural policy systems is formed naturally and extensively in the process of social system transformation in China. These systems contain a large number of planned economy legacy, and the color of interest protection of industries and sectors is very strong. These make the system function related to the cultural development lack authority, impartiality and fairness, which is extremely unfavorable to the promotion of our country’s cultural soft power.

\section{Insufficient Development of Cultural Market and Low Theoretical Level of Cultural Industry}

China has unlimited cultural resources, which can be said to be a great country of cultural resources. Excellent traditional culture of the Chinese nation has left us a precious cultural heritage, but today, while we are advocating economic construction, our country's cultural resources and cultural industry have not formed a good relationship of mutual promotion. In the development of cultural industry,our country's research and extraction of traditional cultural resources is severely inadequate and the essence of traditional culture has not been fully demonstrated.

As a result, a large number of our country's cultural resources have been laid aside and buried for a long time, losing their comparability and competitiveness in the face of western culture. Especially when the research level of cultural industry theory is low, the development of cultural market lacks the necessary theories as the key guidance. This makes the improvement of China's cultural soft power still lack vitality in the development of cultural industry even though it has strong motivation.

\section{Lack of Competitiveness of Cultural Industry}

Firstly, the concentration and scale of our country's cultural industry is not high. At present, there are many businesses and companies in China's cultural market, but most of them are small. These small businesses have led to less resource concentration and fewer competitive brands. Therefore, the extension of the cultural industry chain has certain limitations. While the production and sales scale can not become a system, the cultural industry are unable to play out its advantage, which is inseparable from the negative impact of the planned economy. At the same time, China's cultural market has not really perfected. "The development of cultural factor market, cultural property market, cultural talents market and cultural and artistic facilities market is relatively backward.” [1]

Secondly, there is still a huge gap in talents and experts in our cultural industry. In the process of industrial development, the cultural industry lacks those advanced talents who have unique ability for judgment and can grasp the international cultural market. The lack of professional talents makes our cultural industry lag behind the developed countries in 
international competitiveness.

Thirdly, China has a serious trade deficit in cultural industry in the cultural field. At present,China's cultural products import far more than export. Although there is a "China fever" about Chinese culture around the world,our country still exports very little in the terms of cultural products trade. China has a large number of cultural industry development resources, but we do not occupy the best development conditions, which is not enough to tap existing culture. For instance, at present, our country is a low value-added manufacturing link in many fields and is in a trade surplus position in the manufacturing industry, which indirectly indicates that China has a low development level of our cultural soft power. [2]

\section{Countermeasures to Enhance China's Cultural Soft Power}

\section{Promote Excellent National Culture and Enhance the Attraction of National Culture}

Cultivate the sense of identity with the national culture and explore the essence of the national culture. At present, due to the impact of multiculturalism and the impact of social transformation, the Chinese people are also worried and confused about their cultural orientation. In fact, our national culture not only has rich connotation, but also has infinite value and extensive social adaptability. This national spirit has been a powerful ideological driving the Chinese nation to keep growing and grow stronger over the past 5,000 years. [3]

Cultures from all over the world are constantly blending with China's traditional culture. How to realize the harmonious coexistence of globalization and localization is the key problem we need to study at present. We should grasp the relationship between modern culture and traditional culture rationally and scientifically, and respect the aesthetic differences of western cultural values. At the same time, we should actively explore the essence from the rich cultural resources of the Chinese nation, and understand the true meaning of life.

First of all, we should strengthen the protection of China's traditional cultural resources, focus on protecting those valuable material and intangible cultural heritage, and to prevent the gradual loss of traditional culture due to the development of modern civilization. Secondly, we should study, explore and sort out the existing cultural resources, further sort out the generation and development rules of our national culture, and make scientific predictions for the future cultural development. Thirdly, we should integrate the national traditional culture into the current social political and economic development and further promote the industrialization of culture.

On the one hand, we should set up a special department for the development of cultural resources quickly,which is conducive to a comprehensive arrangement and investigation of China's existing cultural resources. At the same time, to promote the development of national culture in China. On the other hand, we should appropriately increase economic input, establish a database for storing cultural resource information as soon as possible and reasonably predict and evaluate the existing cultural resources. In this way, China's traditional culture will go abroad with the image of Chinese brands, which will be known to more people around the world.

To Strengthen the Reform of the Political System of the Socialist, Providing Institutional Guarantee for Cultural Soft Power

Promoting the reform of the socialist political system is the key to enhancing China's 
cultural soft power. The development of socialist democracy with Chinese characteristics is also an important condition for the promotion of cultural soft power.

At present, China's political system has unprecedented superiority, but some systems and operations need to be further optimized and improved. Four Cardinal Principles are the foundation of our country's founding, therefore, we must always adhere to Four Cardinal Principles and oppose bourgeois liberalization. This is not only the basis for maintaining China's social stability, but also an important political guarantee for deepening reform and opening up and promoting social modernization.

We must proceed from the actual situation of our country and actively deal with the existing problems in the current social development of our country. Political restructuring should be accelerated and the public should always follow the path of socialist political development in China with a positive attitude and steady steps. The government should firmly oppose copying the western capitalist political model, and further improve the people's congress system in our country. At the same time, the government should always adhere to ruling for the people, run state affairs according to law, persist in the people's democratic dictatorship. Only in this way can we create a good political environment for the promotion of our cultural soft power and keep the correct political direction in the process of the promotion of our cultural soft power.

\section{To Strengthen Independent Innovation and to Increase the Vitality and Creativity of Culture}

Innovation is a driving force for the continuous development of a society, and it is also an important premise for improving China's cultural soft power in the new era. Innovation is the soul and a kind of fresh vitality, which is an important entry point for the development of social and cultural construction in China. Therefore, in the process of enhancing China's cultural soft power, we should not only actively learn from and absorb the advanced cultural achievements of other countries, but also propaganda China's excellent traditional culture. Starting from the reality of China's cultural soft power and the spiritual needs of the people, it is rooted in the strategic practice of China's cultural development. Our country should strengthen the independent innovation of culture so as to enhance the vitality and creativity of our culture.

"Bring doctrine" cannot prompt China's cultural construction to catch up with advanced countries. Only through independent innovation can we realize the greatest value of our social culture on the basis of self-reliance. Only from the actual situation of our country can we create socialist culture with Chinese characteristics for the need of China's social development and the need of the people. Therefore, we should enhance the charm of culture and promote the improvement of China's cultural soft power.

Under the current situation of international trade deficit of Chinese cultural products, we must enhance the comprehensive competitiveness of the cultural industry through independent cultural innovation. The government should increase support and investment in cultural independent innovation and create independent intellectual property. At the same time, China should produce cultural products with strong attraction, rich content and various forms. Only in this way can we improve the comprehensive competitiveness of our cultural industry and expand the influence of our culture in the world. We will establish a new model for the development of cultural soft power with Chinese characteristics and open up the whole situation of enhancing China's cultural soft power. 


\section{Reference}

[1] Liu Zhihua, Liu Hui. Cultural Soft Power: Foreign Experience and Reference[J]. Journal of University of Jinan. 2008(4).

[2] Tang Jin, Big country policy: China's soft power and soft power strategy leading to the path of great power[M]. Beijing: People’s Daily Press. 2010.

[3] Liu Kang, National Image and Government Communication[M]. Shanghai: Shanghai Jiao Tong University Press. 2010.

[4] Zhu Yaoxian, on improving the soft power of our country's culture and promoting the construction of cultural power[J]. Journal of China Executive Leadership Academy Pudong. 2012, 02:40-44.

[5] Li Shuqun, strengthen cultural consciousness, improve cultural self-confidence and achieve cultural self-improvement[J]. Journal of the Party School. 2011, 06:25-29.

[6] Deng Xianchao, Huang Xiaoxia. A preliminary study on Xi Jinping's ideas of cultural soft power[J]. Journal of Jiangxi University of Science and Technology. 2014, 06. 